\title{
Experience and expectations of transition to higher education: a qualitative exploration
}

\author{
Goldring, T, Harper E, Jassal R, Joseph L, Kelly, A, Mulrooney, H*, Piper, I \& Walker, H \\ School of Life Sciences, Pharmacy \& Chemistry, Kingston University
}

${ }^{*}$ Corresponding Author*: hilda.mulrooney@kingston.ac.uk

Keywords: Transition; Support; Clarity; Belonging

\section{Abstract}

Transition to higher education is challenging, and more so for some groups. The transition from Level 3 foundation year into Level 4 is an opportunity to explore student perspectives on transition. Qualitative survey and focus group data were collected from current and previous Level 3 students, to ascertain student perceptions about induction, level of belonging, confidence about Level 4 and to identify useful support sources. Over a third of eligible Level 3 students $(n=102)$ participated, but participation amongst eligible Level 4, 5 and 6 students was limited. Despite the heterogeneous nature of Level 3 students the majority recognised the value of the foundation year. Most Level 3 students did not identify with the university. Those who did highlighted the importance of social outlets such as clubs and societies. A major cause of dissatisfaction was perceived lack of clarity about the foundation year, including the programme, subjects and physical location of the course. This was apparent across all ethnicities, age groups and genders. Among previous Level 3 students, personal sources of support were uniformly valued although the precise source varied by year of study. Support from academic staff, via office hours and as personal tutors, was rated as most important. Enabling academic staff to offer support to students throughout their studies, and clear consistent information available throughout an ongoing transition, may help to minimise these issues.

\section{Introduction}

Successful transition to higher education is required for undergraduate students to achieve academic success (Parker et al, 2017; Strayhorn, 2012). Transition can be defined as the internal process occurring when students move to the unfamiliar while adjusting to higher education (Perry \& Allard, 2003). How students respond to the multiple changes associated with higher education, such as new learning environment, altered finances, social and academic changes (Cheng et al, 2015), is shaped by factors such as previous educational and life experiences (Ozga \& Sukhnandan, 1998), expectations of higher education (Lowe \& Cook, 2003; Cook \& Leckey, 1999) and preparedness (Lowe \& Cook, 2003). All of these represent potential challenges to institutions as well as students (Greenbank, 2007; Briggs et al, 2012). If this transition is unsuccessful, students are less likely to continue in higher education (Katanis, 2000; Mclnnes et al, 2000). Therefore transition, and how it is negotiated is of real importance (Hussey \& Smith, 2010) to the student and the university.

Support at the beginning of academic life matters (Select Committee on Education and Employment, 2001), since the majority of students who leave higher education do so early on in their studies (Thomas, 2012a; Harvey et al, 2006; Yorke, 1999). One important route into higher education is the foundation year, offered by many UK universities to those without the requisite 
qualifications or subjects to enter their desired programme of university study directly. The Science, Technology, Engineering \& Mathematics (STEM) foundation year is a key part of the Kingston University recruitment drive, attracting large numbers of applicants annually. Approximately $10 \%$ of those who successfully complete it do not progress into Level 4 at the university- a significant loss to the university and a setback to those students. The STEM foundation year runs at a local sister college, Kingston College, situated close by the main university campus. Foundation (Level 3) students are registered to the college and the university with identification cards for both; they are eligible to partake in university and college activities, clubs and societies. Successful completion of the foundation year results in direct progress into Level 4 at the university. Understanding the experiences, hopes and expectations of current Level 3 students taking the foundation year, and identifying the sources of support that previous foundation students found helpful, could help to ensure that the university induction programme meets the needs of this diverse group. It will also provide insight into the wider student experience of transition.

\section{Methods}

Ethics approval was granted by the Kingston University Centre for Higher Education Research and Practice Research Ethics Committee. Quantitative data was collected by questionnaire and qualitative data by focus groups and through open ended text boxes within the questionnaires.

\section{Quantitative data}

Background information collected from all participants included age, gender, ethnicity and year of study.

\section{Level 3 respondents}

Students were asked whether the induction helped them to integrate into their course, whether they felt part of the college and/or the university and their current and anticipated confidence levels about entering Level 4. Five point Likert rating scales were used (from 'strongly agree/ completely confident' to 'strongly disagree/ completely unconfident'). Open text boxes to record additional comments were included.

\section{Levels 4, 5 and 6}

Students were asked to retrospectively rate different named types of support in order of perceived importance during Level 3 study (from 1 to 7; 1 being most and 7 being least important). In addition they were asked to rate the extent to which they agreed that they felt part of the university and/or part of the college. Retrospective confidence levels about moving from Level 3 to Level 4 were gathered using a five point Likert rating scale (from 'completely unconfident' to 'completely confident'). Students could add additional comments to open text boxes.

\section{Data collection}

Level 3 questionnaires were distributed during taught classes common to several STEM pathways. A brief introduction to the project was given with a participant information sheet. Completion of questionnaires was during the session (approximately 10 minutes).

Online distribution of the questionnaires for Levels 4,5 and 6 students was used, with personalised invitations to participate and a link to the survey distributed via university email, to avoid singling out foundation degree students within large taught modules.

\section{Focus groups}

Students at all levels could participate in focus groups at the university. Those who wanted to participate were emailed to organise mutually agreeable dates and times. Records of all email addresses were destroyed when focus groups were organised. All sessions were facilitated by two student partners; discussions were recorded using a voice recorder and contemporaneous notes.

\section{Data analysis}

Data were analysed by age, gender, year of study and ethnicity to determine whether these factors influenced participant responses. Key themes from qualitative data were identified using basic thematic analysis. Qualitative data included both focus group data and open text boxes within the questionnaires. 


\section{Results}

\section{Participants}

Participant demographic data is shown in Table 1. Participants were limited to current Level 3 students ( $n=102$ respondents) at the college, and previous Level 3 students now in Level 4 ( $n=10$ respondents), Level 5 ( $n=18$ respondents) and Level 6 ( $n=28$ respondents) at the university. These response rates represented 37.4\%, (Level 3), 4.7\% (Level 4), $7.8 \%$ (Level 5 ) and $19.6 \%$ (Level 6 ) of eligible students respectively. Two focus groups were held. No secondary data were used.

\section{Level 3 responses}

No Level 3 students responded to the invitation to attend focus groups. Their qualitative data comprised 124 in-questionnaire comments. Three major themes arose: belonging, induction and confidence.

\section{Belonging}

The largest proportion of comments overall $(n=48 ; 39 \%)$ related to whether or not students felt that they belonged at the university and/or the college. While a small number valued the fact that they were effectively part of both, the majority of respondents $(n=29 ; 60 \%)$ felt part of the college, not the university (Table 2 ), largely due to the location of the foundation year at the college $(n=16 ; 55 \%)$. Some respondents felt that there was little effort to help them feel part of the university. Those who felt part of both the college and the university were a minority ( $n=7 ; 15 \%)$, and they specified the important role of clubs and societies. A small number of students $(n=8 ; 17 \%)$ felt part of neither the university nor the college.

\begin{tabular}{|c|c|c|c|c|}
\hline & Level 3 & Level 4 & Level 5 & Level 6 \\
\hline \multicolumn{5}{|l|}{ Gender } \\
\hline Males & $46(45)$ & $3(30)$ & $6(33)$ & $20(71)$ \\
\hline Females & $51(50)$ & $5(50)$ & $12(67)$ & \\
\hline PNS* $^{*}$ & $4(4)$ & $2(20)$ & $0(0)$ & $1(4)$ \\
\hline Other & $1(1)$ & $0(0)$ & $0(0)$ & $0(0)$ \\
\hline Total & $102(100)$ & $10(100)$ & $18(100)$ & $28(100)$ \\
\hline \multicolumn{5}{|l|}{ Age } \\
\hline$<21$ years & $67(66)$ & $7(70)$ & $4(22)$ & $0(0)$ \\
\hline$\geq 21$ years & $20(20)$ & $2(20)$ & $13(72)$ & $27(96)$ \\
\hline PNS* $^{*}$ & $15(14)$ & $1(10)$ & $1(6)$ & $1(4)$ \\
\hline Total & $102(100)$ & $10(100)$ & $18(100)$ & $28(100)$ \\
\hline \multicolumn{5}{|l|}{ Ethnicity } \\
\hline White & $27(26)$ & $1(10)$ & $9(50)$ & $15(54)$ \\
\hline Black & 19 (19) & $2(20)$ & $2(11)$ & $5(18)$ \\
\hline Asian & $35(34)$ & $4(40)$ & $3(17)$ & $4(14)$ \\
\hline Mixed & $8(8)$ & $0(0)$ & $3(17)$ & $1(4)$ \\
\hline PNS* & $13(13)$ & $3(30)$ & $1(5)$ & $3(11)$ \\
\hline Total & $102(100)$ & $10(100)$ & $18(100)$ & $28(100)$ \\
\hline
\end{tabular}

Table 1 Demographics of study participants expressed as numbers (\%). ${ }^{*} \mathrm{PNS}=$ prefer not to say. 
Experience and expectations of transition to higher education: a qualitative exploration

\begin{tabular}{|c|c|}
\hline Statement & Themes, subthemes and illustrative quotes \\
\hline $\begin{array}{l}\text { 'I feel part of } \\
\text { Kingston } \\
\text { university' } \\
\text { AND } \\
\text { 'I feel part of } \\
\text { Kingston } \\
\text { college' }\end{array}$ & $\begin{array}{l}\text { 1. Included in both }(\mathrm{n}=7,15 \%) \text { : } \\
\text { 'I can participate in uni societies \& use both sites facilities' } \\
\text { 2. Part of college, not uni ( } \mathrm{n}=29,60 \%) \text { : } \\
\text { Societies help ( } \mathrm{n}=2,7 \%) \text { : } \\
\text { 'Only in societies' } \\
\text { Lack of effort ( } \mathrm{n}=3,10 \%) \text { : } \\
\text { 'I don't feel much is done to make us feel like university students' } \\
\text { Mature students ( } \mathrm{n}=2,7 \%) \text { : } \\
\text { 'College doesn't feel like a place for mature students' } \\
\text { Lack of integration ( } \mathrm{n}=6,21 \%) \text { : } \\
\text { 'I expected more integration preparation for university' } \\
\text { No lectures at university ( } \mathrm{n}=16,55 \%) \text { : } \\
\text { 'Feel like I'm still at school, I do not visit the university much, no lectures there' } \\
\text { 3. Neither ( } \mathrm{n}=8,17 \%) \text { : } \\
\text { 'As lessons are not taught at uni but I don't class myself as a college student } \\
\text { either' } \\
4 . \text { Misc. ( } \mathrm{n}=4,8 \% \text { ) } \\
\text { 'Nothing that interests me' }\end{array}$ \\
\hline
\end{tabular}

Table 2 Overall qualitative feedback from Level 3 students relating to belonging at the university and/or the college. This table summarises 48 comments related to whether or not students felt that they belonged at the university and/or the college.

More females than males did not feel part of the university (57\% and $38 \%$ respectively), although $21 \%$ of males and $13 \%$ of females felt at home both within the university and the college.

By ethnicity, $53 \%$ of white, $57 \%$ of black, $72 \%$ of Asian and $25 \%$ of mixed race students did not feel they belonged at the university. Similar proportions felt at home both at the university and the college, and the major factors identified by them were the facilities and societies that helped them feel at home.

The same themes were apparent by age. Approximately two thirds of both age groups stated that they did not feel part of the university.
A greater proportion of those $<21$ years $(17 \%)$ compared with those $\geq 21$ years $(1 \%)$ did not feel at home either at the college or the university.

\section{Induction}

$35 \%$ of total comments related to their induction into the foundation course, of which $47 \%(n=20)$ related to a lack of clarity about the foundation year. This included confusion about the location and uncertainty about their subjects (Table 3). No differences in response to induction were seen by gender. More older ( $\geq 21$ years) than younger ( $<21$ years) students felt negatively about the induction $(50 \%$ versus $11 \%$ respectively). Similarly lack of clarity was highlighted across all ethnicities (white 60\%, Black $40 \%$ \& Asian $53 \%$ respectively). 
Experience and expectations of transition to higher education: a qualitative exploration

\begin{tabular}{|c|c|}
\hline Statement & Themes, subthemes and illustrative quotes \\
\hline $\begin{array}{l}\text { 'The } \\
\text { induction } \\
\text { helped me } \\
\text { feel } \\
\text { comfortable } \\
\& \\
\text { integrated } \\
\text { into my } \\
\text { course' } \\
\text { AND } \\
\text { 'The course } \\
\text { was } \\
\text { accurately } \\
\text { described } \\
\text { to me on } \\
\text { application/ } \\
\text { clearing' }\end{array}$ & 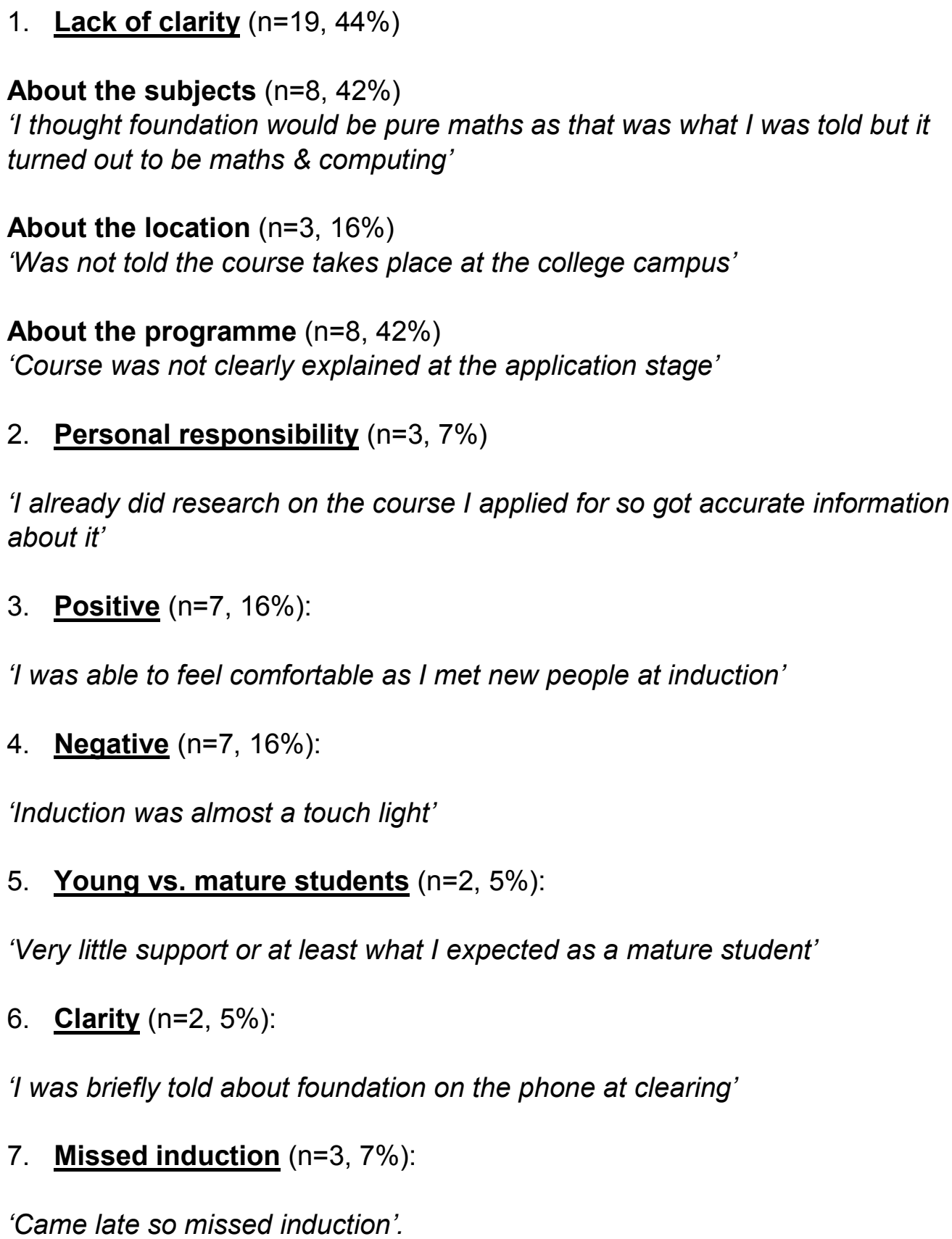 \\
\hline
\end{tabular}

Table 3 Overall qualitative feedback relating to induction from Level 3 students. This table summarises 43 comments related to their induction into the foundation course. 


\begin{tabular}{|c|c|}
\hline Statement & Themes, subthemes \& illustrative quotes \\
\hline $\begin{array}{l}\text { 'How } \\
\text { confident } \\
\text { do you feel } \\
\text { NOW about } \\
\text { going into } \\
\text { Level 4' } \\
\text { AND } \\
\text { 'How } \\
\text { confident } \\
\text { do you } \\
\text { THINK you } \\
\text { will feel at } \\
\text { the end of } \\
\text { Level 3?' }\end{array}$ & $\begin{array}{l}\text { 1. Confidence }(\mathrm{n}=4,18 \%) \text { : } \\
\text { 'The foundation year lecture format is similar to that of university lectures' } \\
\text { 2. Readiness/preparedness ( } \mathrm{n}=7,32 \%) \text { : } \\
\text { 'Feel I will be more prepared with dealing with level } 4 \text { now \& even more after } \\
\text { passing leve/ 3' } \\
\text { 3. Negative ( } \mathrm{n}=8,36 \%) \text { : } \\
\text { 'Confused...disappointed' } \\
\text { 4. Positive ( } \mathrm{n}=1,5 \%) \text { : } \\
\text { 'Easy to understand \& has a good atmosphere' } \\
\text { 5. Lack of clarity ( } \mathrm{n}=2,10 \%) \text { : } \\
\text { 'Still unsure as to whether / will change my chosen degree' }\end{array}$ \\
\hline
\end{tabular}

Table 4 Qualitative feedback from Level 3 respondents related to confidence about Level 4 study. This table summarises 22 comments related to confidence about moving into Level 4 study.

\section{Confidence}

Twenty two comments related to confidence about moving into Level 4 study (Table 4). Mixed emotions relating to readiness to move into Level 4 were seen across all ethnicities and both genders. A greater proportion of negative comments were seen from students aged $\geq 21$ years compared with those aged $<21$ years $(29 \%$ versus $18 \%$ respectively). For students $\geq 21$ years, negative comments related to concerns about their own readiness to enter Level 4.

\section{General}

Eleven general comments were made, more than half of which related to a wish for greater links with the university (data not shown).

\section{Level 4, 5 and 6 students}

Qualitative data was limited to 3 areas about which students were asked to comment; namely belonging, what would have helped increase their confidence in transition from
Level 3 to 4 and the appropriateness of the workload at Level 3.

\section{Belonging:}

Those now at Levels 4,5 and 6 identified several of the same issues as the Level 3 students. They did not feel part of the university during their foundation year.

This sense of not belonging related both to the geographical location of the foundation year:

\section{"Seeing there was no lectures given here I felt very out of place." [Level 6 female]}

and to the atmosphere and teaching style at the college:

\section{'I found the environment unfriendly and added extra stress to my studies" \\ [Level 5 female].}


Experience and expectations of transition to higher education: a qualitative exploration

Like current Level 3 students, many previous foundation students had felt part of neither the university nor the college:

"It was a bit like being stuck in a weird
limbo. We weren't really university
students, but we weren't college
students either"
[Level 5 female]

Focus group feedback agreed; students suggested that moving the foundation year to the university would enhance belonging.

\section{Confidence}

Better integration with the university was strongly identified as a factor which would have increased student confidence in the transition from Level 3 to 4 . In addition, the importance of personal tutors, availability of taught material online and meeting students from higher levels of their degree were identified by Level 5 students.

Focus group feedback agreed that meeting previous foundation students who had progressed to undergraduate study, would improve the Level 3 experience.

\section{Perceived appropriateness of Level 3 material}

The majority of responses were positive with regard to the foundation year material, and this increased with year of study. Eighty one $\%$ of Level $6,70 \%$ of Level 5 and $25 \%$ of Level 4 responders agreed that Level 3 material was appropriate.

\section{Discussion}

This study focused on the experience of foundation programme students at one university. Nonetheless the findings have wider relevance. The delivery of material across partner institutions is not unusual, and all higher education students experience a transition from Level 3 to Level 4 study.

In this case, the majority of students surveyed were positive about the foundation programme, notable given the heterogeneous group who undertake it. Nonetheless the feedback highlighted important issues likely to impact upon the effectiveness of transition for all Level 3 students.
The importance of belonging has been identified as a critical component in helping students to integrate and engage within higher education (Thomas, 2012b). Feeling that they matter to the institution and are cared for by it helps ensure that students engage and are retained (Strayhorn, 2012; Hausman, 2009; Freeman et al, 2007). A sense of belonging can be fostered by early engagement with academic staff (Thomas, 2012b). Given this, it is worrying that approximately $60 \%$ of Level 3 students who responded did not feel they belonged at the university. Part of this may reflect the physical location of the foundation year, a few minutes away from the main university campus. Despite their geographical proximity, our data suggests that belonging does not just relate to physical location but to the learning environment fostered within different institutions. This has been recognised in other work (Reay et al, 2010) and may reflect differences between the teaching and learning environments, relationships with and support from staff between Levels 3 and 4 (Crabtree et al, 2007). Qualitative studies with students have identified university-led enablers of successful transition (Bowles et al, 2011). These include orientation, learning at university, facilities and social aspects. Many foundation year students are from black and minority ethnic (BME) groups, have entered higher education through non-traditional routes, are first in their families to enter higher education or are mature students; traditionally hard-to-reach groups identified as likely to face more difficulties with transition than traditional students (O'Donnell \& Tobell, 2007; Reay et al, 2010; Parker et al, 2017). Some applicants may not be realistic about their chances of success at university without first taking a foundation year, while for others, Level 3 study may not represent what they expected from university life. It has been shown that students from lower socioeconomic backgrounds, who have experienced study delay in higher education, or who were less autonomously motivated for study were less likely to be flexible learners (Donche \& Van Petegem, 2006). Addressing student expectations, establishing learner identities, provision of adequate support, enabling peer group interactions and approachable staff are all helpful strategies (Briggs et al, 2012). Central to engaging students are teaching styles and teaching staff (Zepke \& Leach, 2010), and 
personal support by academic staff was clearly valued in this study. This agrees with Money et al (2017), who found that students value support and relationships (with academic staff and their peers). Fostering these relationships will encourage student engagement, but staff need time and resource to enable this to happen.

Perceived lack of clarity about the foundation programme was widespread. This matters because a mismatch in expectations can result in lack of engagement or withdrawal from studies (Byrne et al, 2012). Also of concern was the lack of satisfaction apparent among BME students. For many UK institutions, narrowing the BME attainment gap is a key priority, and this needs further exploration.

Induction represents the start of the student journey. Our data suggests that students viewed induction as an event, delivered at a specific time point at the beginning of the academic year. This is problematic and others have suggested that it should not be an event but an ongoing process (Hussey \& Smith, 2010; Lowe \& Cook, 2003; Tinto, 1993), fostering interactions with peers, social and academic integration and academic preparation. Acclimatisation to higher education is likely to take place throughout the first year of study, and induction is merely the first part of it (Brooman \& Darwent, 2014). Giving new students a social and information overload typically within the first week of term and assuming they will be able to integrate may not be in their best interests, ultimately meeting neither their needs nor those of the institution. Although the roles of clubs and societies were highlighted by those students who did identify with the university, not all students have the confidence, time or interest to engage with social activities. For this reason, induction activities should be held within the academic sphere so that all students may benefit from them (Thomas, 2012a). There may be many reasons why students choose not to engage with social activities within higher education, and the diversity of this cohort in terms of age and ethnicity suggests that many are nontraditional entrants. Universities need to adapt and offer cultures that welcome diversity (Johnson et al, 2007; Zepke \& Leach, 2005). Our data suggests that getting the beginning right may be an important part of helping students to engage, settle in and develop securely as learners. This may in turn increase student retention.

\section{Conclusion}

The issues highlighted here included the importance of fostering a sense of belonging, clarity about programmes of study and the nature of induction programmes offered. Regardless of the type of educational institution or method of delivery, these are pertinent to all higher education institutions to enhance student experience and engagement. A clear description of courses to students to avoid a mismatch in their expectations is needed. An induction programme, carried on throughout the first year and placed with the academic sphere, is needed to smooth student transition from Level 3 to 4 . This will require university investment allowing staff time and resource to adequately support students. Further research into levels of satisfactions among BME students on the foundation year is required. Fostering a sense of belonging in Level 3 students may help to enhance retention.

\section{References}

Bowles, A., Dobson, A. \& Fisher, R. (2011). An exploratory investigation into first year student transition to university. In Krause, K., Buckridge, M., Grimmer, C. \& Purbrick-lllek, S. (Eds.) Research and Development in Higher Education: Reshaping Higher Education 34: 61 - 71. Available at:

http://www.herdsa.org.au/system/files/HERDS A_2011_Bowles.PDF

Briggs, A.R.J., Clark, J. \& Hall, I. (2012) Building bridges: understanding student transition to university. Quality in Higher Education 18 (1): 3-12. DOI: 10.1080/13538322.2011.614468

Brooman, S. \& Darwent, S. (2014) Measuring the beginning: a quantitative study of the transition to higher education. Studies in Higher Education 39(9): 1523-1541. DOI: $10.1080 / 03075079.2013 .801428$

Byrne, M., Flood, B., Hassall, T., Joyce, J., Montano, J.L.A., Gonzalez, J.M.G. \& TarnaGermanou, E. (2012) Motivations, expectations and preparedness for higher 
Experience and expectations of transition to higher education: a qualitative exploration

education: A study of accounting students in Ireland, the UK, Spain and Greece. Accounting Forum 36: 134-44. DOI: 10.1016/j.accfor.2011.12.001

Cheng, M., Pringle Barnes, G., Edwards, C., Valrakis, M. (2015) Transition skills and strategies. Transition Models and how Students Experience Change. QAA: Scotland.

Cook, A. \& Leckey, J. (1999) Do Expectations Meet Reality? A Survey of Changes in First Year Student Opinion. Journal of Further and Higher Education 23(2): 157-71. DOI: 10.1080/0309877990230201

Crabtree, H., Roberts, C. \& Tyler, C. (2007) Understanding the Problems of Transition into Higher Education. Retrieved from: http://www.ece.salford.ac.uk/proceedings/pap ers/35_07.pdf

Donche, V. \& Van Petegem, P. (2006) Learning patterns in higher education: the influence of personal and contextual factors. Paper presented at the British Educational Research Association Annual conference, University of Warwick, 6-9 September 2006.

Freeman, T., Anderman, L. \& Jensen, J. (2007) Sense of Belonging in College Freshmen at the Classroom and Campus Levels. The Journal of Experimental Education, 75, 203-220. Retrieved from http://www.jstor.org/stable/20157456

Greenbank, P. (2007) From foundation to honours degree: The student experience. Education and Training 49(2): 91-102. DOI: 10.1108/00400910710739450

Harvey, L., Drew, S. \& Smith, M. (2006) The First Year Experience: A review of Literature for the Higher Education Academy. York: HEA.

Hausmann, L.R., Ye, F., Schofield, J.W. \& Woods, R.L.. (2009) Sense of belonging and persistence in white and African American firstyear students. Research in Higher Education, 50, 649-669. Available at: https://www.jstor.org/stable/40542320

Hussey, T. \& Smith, P. (2010) Transitions in higher education. Innovations in Education and
Teaching International 47:2. DOI: 10.1080/14703291003718893

Johnson, D., Alvarez, P., Longerbeam, S., Soldner, M., Inkelas, K.K., Leonard, J.B. \& Rowan-Kenyon, H. (2007) Examining sense of belonging among first year undergraduates from different racial/ethnic groups. J College Students Development, 48, 525-42.

Katanis, T. (2000) The role of social transition in students' adjustment to the first-year of university. Journal of institutional Research, 9, 100-10.

Lowe, H. \& Cook, A. (2003) Mind the Gap: Are Students prepared for Higher Education? Journal of Further and Higher Education, 27, 53-76. DOI: 10.1080/03098770305629

Mclnnes, C., James, R. \& Hartley, R. (2000) Trends in the first year experience: In Australian universities, Centre for the Study of Higher Education, University of Melbourne. ISBN: 0642448647

Money, J., Nixon, S., Tracy, F., Hennessy, C., Ball, E. \& Dinning, T. (2017) Undergraduate student expectations of university in the United Kingdom: What really matters to them? Cogent Education, 4, $1301855 . \quad$ DOI: 10.1080/2331186X.2017.1301855

O'Donnell, V.L. \& Tobell, J. (2007) The transition of adult students to higher education: legitimate peripheral participation in a community of practice? Adult Education Quarterly, 57, 312-328. DOI: $10.1177 / 0741713607302686$

Ozga, J. \& Sukhnandan, L. (1998) Undergraduate Non-Completion: Developing an Explanatory Model. Higher Education Quarterly, 52, 316-33. DOI: 10.1111/14682273.00100

Parker, H., Hughes, A., March, C., Admed, S., Cannon, J., Taylor-Steeds, E., Jones, L. \& Page, N. (2017) Understanding the different challenges facing students in transitioning to university particularly with a focus on ethnicity. New Directions in the Teaching of Physical Sciences, 12. DOI: 10.29311/ndtps.v0i12.2450 
Experience and expectations of transition to higher education: a qualitative exploration

Perry, C. \& Allard, A. (2003) Making the connections: Transition experiences for firstyear education students. Journal of Educational Enquiry 4(2): 74-89. Available at: https://www.researchgate.net/publication/2410 62357_Making_the_connections_Transition_e xperiences_for_first-

year_education_students?enrichld=rgreq-

3fdca642c3ffb2e103107d700fac6f92-

XXX\&enrichSource $=$ Y292ZXJQYWdIOzIOMT

A2MjM1NztBUzoxODYwNzU0NjkzMjgzODRA MTQyMTM3NTI1NzQ3NQ\%3D\%3D\&el=1_x 2\&_esc=publicationCoverPdf

Reay, D., Crozier, G. \& Clayton, J. (2010) 'Fitting in' or 'standing out': working class students in UK higher education. British Educational Research Journal, 36, 107-124. DOI: $10.1080 / 01411920902878925$

Select Committee on Education and Employment (2001) House of Commons 6th Report, 23.01.01. Available from: https://publications.parliament.uk/pa/cm20000 1/cmselect/cmeduemp/124/12403.htm

Strayhorn, T.L. (2012) College students' sense of belonging: A key to educational success. New York, NY: Routledge. ISBN: 9781136312397

Thomas, L. (2012a) What works? Facilitating an effective transition into higher education.
Student Writing in Transition Symposium, Nottingham Trent University. DOI: 10.5456/WPLL.14.S.4

Thomas, L. (2012b) Building Student Engagement and belonging in Higher Education at a time of change. Final report from the What Works? Student Retention and Success programme. HEA: York. Available at: https://www.heacademy.ac.uk/system/files/wh at_works_final_report.pdf

Tinto, V. (1993) Leaving College: Rethinking the Causes and Cures of Student Attrition, 2nd edition. Chicago: University of Chicago Press. ISBN-0-226-80449-6

Yorke, M. (1999) Leaving Early: Undergraduate Non-Completion in Higher Education. London: Falmer Press. ISBN9781135707231

Zepke, N. \& Leach, L. (2005) Integration and adaptation: approaches to the student retention and achievement puzzle. Active Learning in Higher Education, 6, 46-59. DOI: $10.1177 / 1469787405049946$

Zepke, N. \& Leach, L. (2010) Improving student engagement: Ten proposals for action. Active Learning in higher Education, 11, 16777. DOI: $10.1177 / 1469787410379680$ 